\title{
METHODS OF HEALTH INSTRUCTION IN THE SECOND AND THIRD GRADES ${ }^{x}$
}

\author{
CAROLYN HOEFER \\ Elizabeth McCormick Memorial Fund, Chicago
}

The first article advocating more practical health instruction in the public schools, which appeared in the September issue of the Elementary School Journal, dealt with two phases of the question: first, the necessity of making a survey of the health condition of all of the children in the schools to determine what health principles should be taught; and second, suggestions for correlating these principles with the work of the first grade and for determining the result of such instruction. How this type of material can be combined with the work of the second and third grades is the problem of this article.

\section{A. HEALTH PRINCIPLES TO BE TAUGHT IN THE SECOND AND THIRD GRADES}

Attention is called to the fact that in the first article it was suggested that certain ideas be inculcated in the first grade, namely, (I) going to bed at seven or eight o'clock, depending on the age of the child, (2) drinking milk three times daily, (3) brushing the teeth every night, (4) drinking a glass of water before breakfast, and (5) eating cooked cereal every morning. The requirements for the second and third grades should, of course, include those of the first grade with certain additions. The value of including in the daily diet both fruit and vegetables, preferably one leafy vegetable, such as lettuce, spinach, etc., in addition to potatoes, is suggested as a leading item of instruction for these grades. Devices for teaching primarily the value of these foods and incidentally other general health principles will be discussed in the following section.

I This is the second of a series of articles on classroom methods for increasing the efficiency of health instruction in the public schools contributed by the Elizabeth McCormick Memorial Fund. Reprints may be obtained from the Elizabeth McCormick Memorial Fund, 848 North Dearborn Street, Chicago, Illinois. 
B. RECOMMENDATIONS FOR TEACHING HEALTH PRINCIPLES IN THE SECOND AND THIRD GRADES

I. Opening exercises.-The opening period of school is always a source of delight to children. They enjoy the singing, the exchange of greetings, and the opportunity of bringing together their varied interests. This period therefore can easily and appropriately become one of health instruction. A method suggested for thus utilizing this period is the use of songs for introducing the study of foods. One song which is suitable for such use is called "Thanks for Daily Blessings." The music as well as the words are found in the book Song Stories for the Kindergarten by Mildred J. Hill (Chicago: Clayton F. Summy \& Co., I896).

In connection with this song an appeal can be made to the experiences of the children and emphasis may be laid on "our food." A talk might be introduced by asking, "What are some of the things we had this morning for which we should be thankful?" As the children name the various things, the teacher may write them on the blackboard, commenting favorably upon the breakfasts consisting of fruit, cooked cereal, toast, and milk or cocoa, thereby using the information as an object lesson for teaching the proper foods children should have for breakfast. As long as children continue to drink tea and coffee, to eat foods fried in fats, or to omit breakfast entirely, there will be need of emphasis upon these facts.

Other songs which may be used for this purpose with pupils in the second and third grades are here suggested:

"The Child and the Apple," "Bed Time," and "The Orchard." Song Echoes from Child Land for the Home, the School, and the Kindergarten." Prepared by Harriet S. Jenks and Mabel Rust. Boston: Oliver Ditson Co., 1896. "The Story of Bread," "The Story of the Apple," and "The Story of Butter."

Song Stories for the Kindergarten. Mildred J. Hill and P. S. Hill. Chicago: Clayton F. Summy \& Co., 1896.

"The Song of the Loaf of Bread." Songs of the Child World, No. I. Alice D.

Riley and Jessie L. Gaynor. New York: John Church Co., I9r2.

"Milking Time," "Sweeping and Dusting," and "The Mill." Songs of the Child World, No. 2. Alice D. Riley and Jessie L. Gaynor. New York: John Church Co., Igr 2.

2. Literature.-There are a number of poems and stories now frequently taught in many schools which can be used to teach the 
ideas which have been selected as most appropriate to these grades and at the same time to lay emphasis on health principles in general. Since it is not hard to obtain copies of a number of such reading exercises, only the bibliography will be included.

\section{POEMS}

"Why Cherries Grow." New Baby World. Mary Dodge. New York: Century Co., I897.

"The Little Girl Who Wouldn't Eat Crusts" and "Playing Store." Rhymes and Jingles. Mary Dodge. New York: Charles Scribner's Sons, 1898.

"Goodies to Eat." Muvver and Me. Robert Livingston. Boston: Houghton Miffin Co., I9I7.

"Dairyman." Four and Twenty Toilers. E. V. Lucas. New York: McDevitt Wilson's, Inc., I9I 2.

"Baking Song." Marian M. George. The Primary Plan Book, March, Igr 2. Chicago: A. Flanagan Co.

"The Story of Baby Corn." Marian M. George. The Primary Plan Book, November, I9r2. Chicago: A. Flanagan Co.

"The Sun at Evening Sets." The Original Poems and Others. Ann and Jane Taylor and Adelaide O'Keefe. New York: Fred A. Stokes Co., I904.

"Good and Bad Children," "Good Night," "In Port," and "The Land of Nod." Child's Garden of Verse. Robert Louis Stevenson. Chicago: Rand McNally \& Co., I902.

STORIES TO TELL CHILDREN

I. Milk

"Just before Supper." Seven o'Clock Stories. Robert Gordon Anderson. New York: G. P. Putnam's Sons, r 920.

"Children of a Sunny Land.-A Strange Milk Wagon." Clara Murray. Wide Awake Readers, Book 3. Boston: Little, Brown \& Co., I9r 5 .

"How Fido Delivered the Milk." Stories for Wakeland and Dreamland. Anne Elizabeth Allen. Springfield, Massachusetts: Milton Bradley Co., I9r3.

2. Fruit

"The Old Apple Tree" and "The Ambitious Apple." Stories to Tell the Littlest Ones. Sara Cone Bryant. Boston: Houghton Mifflin Co., I9I6.

\section{Vegetables}

"The Spirit of the Corn." The Red Indian Fairy Book. Frances Jenkins Olcott. Boston: Houghton Mifflin Co., rgr 7.

"The Story of the Turnip." Marian M. George. The Primary Plan Book, October, rg12. Chicago: A. Flanagan Co.

"How the Beans Came Up." In the Child's World. Emilie Poulsson. Springfield, Massachusetts: Milton Bradley Co., I905. 
"The Dwarf Root's Story of the Pumpkin Seed." The Five Senses. Angela

Keyes. New York: Moffat, Yard \& Co., I9ı I.

"The Little Corn Bringer." The Red Indian Fairy Book. Frances Jenkins Olcott. Boston: Houghton Mifflin Co., I917.

\section{Miscellaneous}

"Columbus and the Egg" and "The Ears of Wheat." Good Stories for Great Holidays. Frances Jenkins Olcott. Boston: Houghton Mifflin Co., I9I 7. "The Long Loaf" and "The Wonderful Pudding." Marian M. George. The Primary Plan Book, March, r912. Chicago: A. Flanagan Co.

"The Child Who Forgot to Wash His Face." Stories for Sunday Telling. Carolyn Sherwin Bailey. Boston: Pilgrim Press, I9r6.

"The Best Prize." The Five Senses. Angela Keyes. New York: Moffat, Yard \& Co., I9I I.

"Clean Peter and the Children of Grubbylea. Ottilia Adelborg. Translated by Ada Wallas. New York: Longmans, Green \& Co., 1905.

Children love to dramatize, and in order that they may do it successfully they must be thoroughly familiar with the story. Therefore, dramatization may well serve not only as an aid in developing clear enunciation and an ability to read with better expression, but also as an aid in teaching health. The ideals depicted in the story become the pupil's ideals of conduct when he has repeatedly lived through the experiences found in the story. The following stories are recommended for three reasons: first, their health content; second, the ease with which they can be dramatized; and third, the natural appeal that they have for children who have an instinctive inclination to represent fairies and elves.

"David and the Good Health Elves." The Story Tellers' Magazine, Vol. V

(January-December, 1917). These stories are copyrighted by the Wisconsin Tuberculosis Society.

"Fairy Do-Nothing and Giant Snap-'Em-Up." Adapted by Catherine Sinclair. Book of Elves and Fairies. Frances Jenkins Olcott. Boston: Houghton Mifflin Co., I9r8.

"The Garden of Health." Fairy Tales from Spain. Edited by J. Munoz

Escamez. New York: E. P. Dutton \& Co.

Rosy Cheeks and Strong Heart. J. Mace Andress and Annie Turner Andress.

New York: Child Health Organization of America, I920.

These stories are, of course, more or less general in their nature, and it remains for the teacher to make the particular application. 
For example, in the story "The Good Health Army Attacks," which is one of the series of "David and the Good Health Elves," the child chosen to be the "Elf of Good Things to Eat" may be selected from the group of children who have fruit every morning for breakfast, or from the group of children who include regularly in their diet a vegetable besides potatoes, according to the point being emphasized at any particular time.

These suggestions will probably suffice to show the possibilities of teaching health during the period set aside for the study of literature.

3. Geography.-As a rule, geography is not started until the third grade, and the child's surroundings become his laboratory. Home geography may then begin with a visit to the wholesale house or market, so that a study may be made of the foods as they are brought into the city. An opportunity presents itself to lay special stress upon the kinds of fruits and vegetables to be found there. When the children have returned from the trip and each one is writing a record of it either as a book of his own or as a part of the class book, they may be interested in bringing to the classroom pictures of fruits and vegetables taken from magazines and catalogs. These may be classified into fruits and vegetables which grow in the surrounding territory and those which come from other regions. Labels from cans and packages may serve as a substitute when the pictures cannot be obtained. Incidentally, the suggestion from the teacher that stewed prunes, or an apple, or an orange is excellent for breakfast may easily find a place in the course of the discussion of the trip.

4. Science: nature-study.-At this point there may be a close correlation between the work in the geography lesson and the work in nature-study. The course of study as it is now being given in the schools frequently includes at this period a study of the parts of the vegetable plants-root, stem, leaf, fruit, flower, seed, etc.and a study of fruit-bearing trees. Children will be interested in being part of the so-called "family tree," and will be eager to group themselves in "branches" of that tree by assuming that they are members of the "tuber family," the "root family," the "leaf family," etc. Eating potatoes places them for that day in the 
"tuber family"; eating turnips, carrots, or beets places them in the "root family," while eating spinach or lettuce will permit them to be included in the "leaf family." Counting the members of the different "families" will arouse a desirable competition, especially if the strongest leaders of the room are placed at the head of the different families.

In connection with the more scientific study of fruits and vegetables, teachers will find helpful material in the sets of "BusyWork Stencils," prepared by G. P. Brown \& Co., Beverly, Massachusetts. There are ten stencils in each set, and the price is ten cents a set. Set No. 22 is composed of fruits; and Set No. 23, of vegetables.

5. History and civics.-History is usually introduced in the second school year. One of the phases first studied is the life of the Indian. This part of the work can easily be adapted to health instruction. Children in the second and third grades delight in "playing Indian," as is evidenced by the large number of children possessing Indian costumes. The question, then, "How many would like to play an Indian game just as the Indians played it?" will meet with a hearty response. Even more intense will be the interest if they are told that they are to make the implements for playing the game just as the Indians actually made them.

There are a number of Indian games which can be adapted to the purpose of health instruction without destroying the historical value. These original games are found in the Twenty-fourth Annual Report of the Bureau of American Ethnology in the section written by Stewart Culin, entitled "Games of the North American Indians."

The game "hoop and pole," described in the report, ${ }^{\mathbf{x}}$ consisted, in part, of throwing darts or poles at the hoop or target as it passed between the parallel lines formed by the Indians. The hoop most commonly used was made of a sapling, the ends being bound together by rawhide.

The most common form of the hoop consisted of strings fastened in such a way that the hoop was divided into quarters, and then woven from side to side until a rather close network, with meshes about an inch square (resembling a spider web), covered the entire

$\therefore$ Pp. 420 ff. 
inside of the frame. The quarters were distinguished by painting the sections of the hoop different colors.

The darts were made of simple straight shafts, of saplings with forked ends which could fasten themselves in the network of the hoop, of long jointed poles, or of pieces of corncob with feathers fastened at one end and sharp pointed sticks about six inches long at the other, the pointed sticks serving the same purpose as the forked ends of the saplings.

There were several ways of playing the game. In some instances the Indians stood in two lines and the hoop was rolled between them, one Indian from each side attempting to throw the dart or pole with sufficient force to fasten it in the network. In other instances the hoop was rolled by one Indian, and two contestants ran after the hoop. The implements in the latter method of playing the game consisted of light rods about 30 inches long, tied in pairs by different colored strings so that each pair could be distinguished. Instead of using the network in the hoop, there were four figures cut upon the hoop or four beads tied at equal distances on the circumference. As one person rolled the hoop, two contestants, each holding a pair of the sticks, ran after it and attempted to throw the sticks in such a manner that when the hoop fell over both sticks would be either above or under these figures or beads. This was a much more difficult way of playing the game, as the sticks usually struck the hoop so that one fell over and the other under, in which case the count was nothing. Tally sticks, about the size of lead pencils, painted green, were used to keep the count of the game.

This description will probably suffice to show the teacher the different kinds of implements that were used-implements easily prepared by the children in the classroom without varying from the original form. The industrial arts course in the second grade includes "work illustrating occupations of the Indians"; hence the making of these implements is in reality already a part of the regular course of study.

As an illustration of the health application, we will assume that the hoop has been divided into four sections by four spokes, each section representing a food: the first, milk; the second, cooked 
cereal; the third, fruit; and the fourth, vegetables. The hoop may be painted different colors between the spokes to designate the different sections. The group is divided into two sections, arranged in parallel lines. As the hoop is rolled between the lines, one child from each side throws a dart, trying to make it pass through a certain section. The method of counting is simple. If the dart is thrown by a child through the section representing milk, the count is ten for his side; and if that child has had three glasses of milk the previous day, the count is doubled. Each of the other sections counts five, and this count is always doubled if the child throwing the dart successfully has eaten on the previous day the food represented by the section through which the dart passes. The number of sections can be increased as soon as different kinds of fruits and vegetables have been studied and when the children become more skilful in throwing the darts. The value of the method of counting described lies in the fact that the child doubles the score he makes for his side if he has followed one of the health rules. It might be well to add here that the children should be informed that the method of giving the sections the names of articles of food has been substituted because many of the details of the method of counting used by the Indians are not known.

The second game, "a stick game," differs from the first in that it is more of a game of chance. In some respects this game has an advantage over the other because it gives all an equal opportunity to score and permits the children who are not skilful in throwing the darts to have a part in the game.

This game ${ }^{x}$ was played with a bundle of sticks about six inches long, tapering to the ends. The number of sticks used varied from ten to one hundred. Of the number used, half were painted red and the other half black, the red representing the men and boys in the camp who wore no eagle feathers and the black representing those who had made their mark on the warpath. Of the black sticks, there were four specially marked. These represented four chiefs who were selected because they had been especially successful in killing their enemies. In addition to the division into two colors there were other markings or notches which were cut to indicate personal prowess.

× Twenty-fourth Annual Report of the Bureau of American Ethnology, pp. $22 \mathrm{ff}$. 
Any number can play this game. The Indians arranged themselves in two rows, A and B, opposite each other. The first person in Row A began the game by dividing a pile of say twenty-five sticks into two parts, one containing the even number and the other the odd number, the odd number usually containing one of the chiefs. Then, holding these two groups behind his back, he shuffled them back and forth. The first person in Row B guessed which group contained the chief. If he guessed correctly, he took the deal. Taking out the chief for his side, he added another chief. Whenever either side lost a chief, a black stick was substituted for the chief lost. The person who guessed correctly then became the dealer for the second person in Row A, and the game thus continued until the four chiefs had been taken and all the black ones had been eliminated. If a player guessed incorrectly, the deal passed to the second person in the opposing row and remained in that row until a correct guess was made. A forfeit was paid by the player if he guessed incorrectly, and the dealer was required to pay a forfeit if the player guessed correctly. The side having the deal "sang" as long as they retained the deal.

In applying this to health instruction, the sticks may have a meaning similar to that in the first game described. The black sticks may represent those who have made their mark on the "warpath for health"; for example, they may represent those who drink milk, those who eat fruit for breakfast, or those who retire at a regular bedtime; the red sticks may represent those who drink tea and coffee or those retiring at a late hour, etc. In fact, it may be well to change the meaning to meet the conditions of the classroom so that the children will not tire of the game. The sticks called the four chiefs should represent the children chosen from the group who are following the laws of health as they are being emphasized in the classroom in the same manner that these represented the Indian chiefs who were chosen for their success in war. The idea of health instruction in this game might be carried even farther by having a "personal history" stick for each child with his name carved on it and with notches representing the different health rules which he has followed. The counting may be in this 
manner: The four chiefs should each count fifteen, and each notch on the other sticks should count one. The forfeits might also be used to an advantage. If the child who is guessing loses, the dealer gives him a health rule (one which he is not at that time following) which he is to follow that day, and it should be the duty of the dealer to inquire the following morning if the forfeit has been paid. If the guesser wins, he gives a health rule for the dealer to follow. With the aid of the teacher these health rules should be along the line of greatest help to the individual pupils. For example, if the one losing is drinking tea and coffee, the forfeit should be, "You shall not drink tea or coffee today and tomorrow."

Space permits the discussion of only two of these games in this article. Those who are interested will find ample material for similar games by consulting the original report.

Summary.-Summarizing, then, it is evident that much health instruction can be given in the second and third grades at the same time instructions is given in other subjects. Part of the time given to opening exercises, literature, geography, science, and history and civics can easily be utilized for the much needed health instruction. If this is done, it is not likely that the work will become monotonous.

\section{MEASURING THE RESULT OF TEACHING HEALTH HABITS}

Three methods for measuring the result of health instruction were suggested in the September issue of the Elementary School Journal and, by way of review, may be mentioned here. They were (I) the follow-up method of individual cases or the pressure which the teacher brings to bear upon the parents to correct physical defects of the children, (2) the score-card method, a device to interest the children in their own condition, and (3) the weighing and measuring of all the children at regular intervals. The first and the third methods will be the same throughout all of the grades, but the second method is a cumulative record and additions are made to the score card used in the first grade. The score card which is recommended for the second grade is presented on page 222. 
SECOND-GRADE SCORE CARD*

\begin{tabular}{|c|c|c|c|c|c|c|c|c|c|c|}
\hline Rule & Sept. & Oct. & Nov. & Dec. & Jan. & Feb. & Mar. & April & May & June \\
\hline $\begin{array}{l}\text { Going to bed at seven } \\
\text { or eight, depending } \\
\text { on age of child }\end{array}$ & 20 & 20 & 20 & 20 & 20 & 20 & & & & \\
\hline Drinking milk three & & & & & & & 20 & 20 & 20 & 20 \\
\hline times daily . ....... & 60 & 60 & 60 & 60 & 60 & 60 & 60 & 60 & 60 & 60 \\
\hline $\begin{array}{l}\text { Brushing teeth every } \\
\text { night. . . . . . . . }\end{array}$ & 20 & 20 & 20 & 20 & 20 & 20 & 20 & 20 & 20 & 20 \\
\hline $\begin{array}{l}\text { Drinking a glass of } \\
\text { water before break- } \\
\text { fast............... }\end{array}$ & 20 & 20 & 20 & 20 & 20 & 20 & 20 & 20 & 20 & 20 \\
\hline $\begin{array}{c}\text { Eating cooked cereal } \\
\text { every morning. . . . }\end{array}$ & 20 & 20 & 20 & 20 & 20 & 20 & 20 & 20 & 20 & 20 \\
\hline Eating fruit once a day & $\cdots$ & 20 & 20 & 20 & 20 & 20 & 20 & 20 & 20 & 20 \\
\hline $\begin{array}{l}\text { Eating one vegetable } \\
\text { in addition to po- } \\
\text { tatoes.............. }\end{array}$ & & & & 20 & 20 & 20 & 20 & 20 & 20 & 20 \\
\hline Total. .... & 140 & 160 & 160 & 180 & 180 & 180 & 180 & 180 & 180 & 180 \\
\hline
\end{tabular}

* The figures represent the total number of times the child obeyed the health rule, one point being given for each school day for fulfilling the health principle involved.

The third-grade score card is the same as the second-grade score card with the exception that certain deductions are made as indicated in the following table.

DEDUCTIONS ADDED TO THE THIRD-GRADE SCORE CARD

\begin{tabular}{|c|c|c|c|c|c|c|c|c|c|c|}
\hline Violation of Health Rules & Sept. & Oct. & Nov. & Dec. & Jan. & Feb. & Mar. & April & May & June \\
\hline $\begin{array}{l}\text { Drinking no milk..... } \\
\text { Drinking tea or coffee. } \\
\text { Going to bed after nine } \\
\text { o'clock............ } \\
\text { Drinking and eating at } \\
\text { the same time or } \\
\text { "w a s hing down } \\
\text { food"............. }\end{array}$ & $\begin{array}{l}20 \\
20\end{array}$ & $\begin{array}{l}20 \\
20\end{array}$ & $\begin{array}{l}20 \\
20 \\
20\end{array}$ & $\begin{array}{l}20 \\
20 \\
20\end{array}$ & $\begin{array}{l}20 \\
20 \\
20\end{array}$ & $\begin{array}{l}20 \\
20 \\
20\end{array}$ & $\begin{array}{l}20 \\
20 \\
20\end{array}$ & $\begin{array}{l}20 \\
20 \\
20\end{array}$ & $\begin{array}{l}20 \\
20 \\
20\end{array}$ & $\begin{array}{l}20 \\
20 \\
20\end{array}$ \\
\hline
\end{tabular}

In conclusion, it may be stated again that the success of health instruction depends to a large extent upon the method of checking up the work. Children of the ages found in the first, second, and third grades cannot realize the necessity of following these rules, and it therefore becomes necessary to devise methods which will show them the results in order that their full and willing co-operation may be obtained. 